\title{
Okul Öncesi Öğretmenlerinin Müzik Etkinliklerinde Orff Yaklaşımını Kullanma Durumları
}

\section{An Analysis on Pre-School Teachers' Views about Using Orff Approach in Musical Activities}

\author{
Esra Yücesan \\ Dr. Öğretim Üyesi, Sinop Üniversitesi Eğitim Fakültesi, Güzel Sanatlar Eğitimi Bölümü, Müzik Eğitimi Anabilim Dalı \\ email: esrayucesan@sinop.edu.tr DORCID ID: https://orcid.org/0000-0001-6657-6086
}

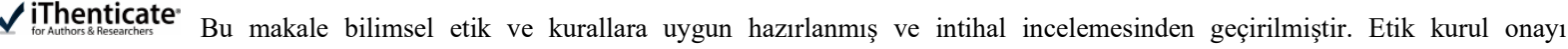 \\ gerektirmemektedir. \\ Atıf (APA 6)/To cite this article \\ Yücesan, E. (2021). Okul öncesi öğretmenlerinin müzik etkinliklerinde Orff yaklaşımını kullanma durumları. Atatürk Üniversitesi Güzel \\ Sanatlar Enstitüsü Dergisi, 27(46), 82-91. https://doi.org/10.35247/ataunigsed.835967 \\ Makale Gönderim Tarihi/Received: 04/12/2020 \\ Makale Kabul Tarihi/Accepted: 05/01/2021 \\ Makale Yayun Tarihi/Published: 29/03/202
}

Research Article/Araştırma Makalesi

Öz

$\mathrm{Bu}$ araştırmada sınıf içi etkinliklerinde Orff Yaklaşımı temelli uygulamalara yer veren okul öncesi öğretmenlerinin Orff Yaklaşımı'nı kullanma durumları tespit edilmek istenmiștir. Bu kapsamda öğretmenlerin Orff Yaklaşımı temelli uygulamalar içinde 'konuşma, şarkı söyleme, enstrüman çalma, hareket ve dans öğrenme alanlarına' yer verme ve çeşitli malzemelerden enstrüman yapma ve etkinlikler içinde kullanma durumları incelenmiștir. Bu amaçla 2019 yılında Sinop İl Merkezi'nde yer alan 3 anaokulunda görev yapmakta olan 14 okul öncesi öğretmeni ile görüșülmüștür. Bulgular, okul öncesi öğretmenlerinin tamamına yakınının konuşma ve şarkı söyleme çalışmaları ile çeşitli malzemelerle enstrüman yapma ve etkinlikler içinde kullanma çalışmalarına yer verdiklerini ortaya koymuştur. Benzer şekilde hareket ve dans uygulamalarına yönelik olarak dans ve hareket doğaçlamaları ile hareket repertuvarı çalışmalarına yer verdikleri, enstrüman ça5lma uygulamalarında ise ritmik egzersizler ve doğaçlama çalışmaları ile topluluk müziği çalıșmaları gerçekleștirdikleri gözlenmiștir. Öğretmenlerin yaklaşık yarısının; hareket ve dans uygulamalarında bedensel farkındalık ve duyarlılaștırma, sabit dans formlarının uygulanması çalışmalarına yer verdiği, az sayıda öğretmenin de enstrüman çalma uygulamalarında tını kalitesi ve çalım tekniklerine yönelik çalışmalar gerçekleştirdiği tespit edilmiştir.

Anahtar kelimeler: Müzik Eğitimi, Okul Öncesi Dönem, Orff Yaklaşımı

\begin{abstract}
This study aims to identify in what situations Orff Approach is used in classroom activities by pre-school teachers who embrace Orff Approach-based practices. In this context, it has been analyzed how teachers use learning areas of the Orff Approach, namely 'speech, singing, playing instruments, movement and dance' and making instruments from various materials and using them in activities. For this purpose, 14 pre-school teachers working in 3 different kindergartens in the city center of Sinop in 2019 have been interviewed. The findings reveal that almost all of the pre-school teachers use speech, singing activities, and make instruments with various materials, and use them in activities. Similarly, in movement and dance practices, they include dance and movement improvisations and movement repertoire, while in instrument playing practices, they perform rhythmic exercises and improvisations, band music practices. It also comes out that in movement and dance practices, approximately half of the teachers make use of bodily awareness and sensitization, practices of fixed dance forms. Likewise, in instrument-playing practices, only a small number of teachers perform practices related to timbre quality and playing techniques.
\end{abstract}

Keywords: Music Education, Pre-School Education, Orff Schulwerk

\section{Giriş}

Erken çocukluk döneminde müzik etkinlikleri ses-müzik dinleme ve ayırt etme çalışmaları, ritim çalışmaları, nefes ve ses çalışmaları, şarkı söyleme, çalgı çalma, yaratıcı hareket ve dans, müzik eşliğinde hareket, müzikli öykü oluşturma gibi uygulamaları kapsamaktadır. Bu etkinlikler çocukların müzikal becerilerini geliştirmelerine paralel olarak bilişsel, dil, motor, sosyal ve duygusal gelişimlerini de desteklemektedir. Buna ek olarak müzik etkinlikleri içinde çalınan basit vurmalı çalgılar, el-göz koordinasyonunu ve aynı anda iki elini birlikte kullanabilme becerisini de kazandırmaktadır (Milli Eğitim Bakanlığı, 2013, s. 48).

$\mathrm{Bu}$ dönemde yapılandıracağımız müzik etkinlikleri, günümüz erken müzik eğitiminde yaygın olarak kullanılan Orff Yaklaşımı temel prensipleri ile de örtüşmektedir (Celebioğlu, 2017, s. 29). Orff Yaklaşımı, besteci ve eğitimci Carl Orff tarafından geliştirilen bir müzik ve hareket yaklaşımıdır. Bu yaklaşım içerisinde müzik; ritmik çalı̧̧malar, hareket ve dans, görsel öğeler, sözlü ve sözsüz şarkılar ve dile ait öğeler ile birlikte kullanılmaktadır (Eren ve diğerleri, 2013, s. 1866). Orff Yaklaşımına dayalı müzik eğitiminin merkezinde müziğin ritim elementi yer alır. Çocuğun doğduğu andan itibaren tüm yaşam aktivitelerinde yer alan bu element müzik, dans ve konuşmay1 birleştiren bir dildir. Bu süreçte çocuğun bedenini bir çalgı olarak kullanması ve doğaçlamalar önemli bir yere sahiptir (Bilen ve diğerleri, 2017, s. 21). Orff Yaklaşımında müzik; hareket, dil, beden ritmi ve vurmalı çalgılarla 
ritmik düzeyde ele alınırken; mırıldanma, şarkı söyleme, ses heceleri ve ezgili çalgılar yoluyla da ezgi düzeyinde ele alınır. Vurmalı ezgili çalgıların kullanımı ile müzikte armonik düzeye varılır. Bu süreçlerde kullanılan ve Orff çalgıları olarak da bilinen bu çalgılar, teknik olarak çalımı son derece kolay olması sebebiyle çocuklara eşlik etme kolaylığı sağlar (Toksoy ve Beşiroğlu, 2006, s. 25; Türkmen, 2017, s. 89).

Eğitim-öğretim süreçlerindeki kazanımlara hizmet etme potansiyeli, Orff Yaklaşımı'nı okul müzik eğitiminde yer verilmesi gereken önemli bir konuma taşır. Bu nedenle müzik eğitimcilerinin bu alanda kendilerini yetiștirmeleri önemlidir. Öyle ki Orff Yaklaşımı temelli uygulamalarda yol gösterici rolünü üstlenen öğretmenin rolü (Türkmen, 2017, s. 89) geleneksel derstekinden farklıdır. Bu süreçlerde öğretmen her şeyi en iyi bilen değildir. Öğrenmeye eşlik eden, yol gösteren, koordinatör ve zaman zaman da üyedir. Öğretmen, çocukların yaratıcılıklarını gösterebilmelerine cesaret verebilecek ölçülü bir yakınlıkla; güven verici, sıcak bir öğrenme ortamı yaratır (Koçak, 2013, s. 12). Çocuklara müzik öğrenimleri sürecinde eşlik, rehberlik eder ve onlara destek olur. Bir sistematiğe bağlı olan hiçbir öğretim metoduna başvurmayan Orff Yaklaşımı’nda öğretmenin -yaklaşımın temel ilkelerini baz alarak- kendi derslerini kendisinin belirlemesi beklenir (Yaprak Kotzian, 2018, s. 139).

Orff Yaklaşımı, içinde bulunulan zamana uyarlanabilen, esnek, açık bir niteliğe sahiptir ve bu niteliği ile öğretmene, öğrenme süreçleri tasarlarken sonsuz aktivite seçenekleri yaratma firsatı verir. Bu aktiviteler tasarlanırken Orff Yaklaşımı'nın odaklandığı sekiz temel öğrenme alanı vardır. Yaprak Kotzian (2018) bu öğrenme alanlarını; konuşma, şarkı söyleme, enstrüman çalma, hareket ve dans, kulak eğitimi, müzik ve dans terimlerini ve sembollerini öğrenme (müzik teorisi), müzik ve dans kompozisyonu yapma ve resim-tiyatro gibi farklı sanat dallarıyla tanışma ve bunları müzik ile kombine etme olarak aktarmıştır. Orff Yaklaşımı'nda bu öğrenme alanlarının birbiri ile bağlantılı şekilde kullanılması öngörülmektedir (Frazee 1987'den aktaran Yaprak Kotzian, 2018, s. 101).

Elbette bunun gerçekleşebilmesi, gerek müzik eğitimcilerinin gerekse müzik eğitimi veren ya da müziği bir öğretim tekniği olarak kullanabilecek farklı disiplin alanlarındaki öğretmenlerin bu alanda iyi yetişmiş, yeterli donanıma sahip olabilmeleri ile mümkündür. Bu bağlamda müzik eğitimi uygulamalarında Orff Yaklaşımı prensiplerinden sıklıkla yararlanan okul öncesi öğretmenlerinin Orff Yaklaşımı'ndan yararlanma düzey ve durumları hakkındaki mevcut durumlarının incelenmesi amaçlanmıştır.

\section{Yöntem}

\subsection{Araștırmanın Modeli}

$\mathrm{Bu}$ çalışma nitel araştırma türünde desenlenmiştir. Nitel araştırma yöntemleri içinde yer alan durum çalışması tercih edilmiştir. Yıldırım (1999, s. 9-10) nitel araştırmayı gözlem, görüşme ve doküman analizi gibi nitel bilgi toplama yöntemlerinin kullanıldığı; algıların, olayların doğal ortamda, gerçekçi ve bütüncül biçimde ortaya konmasına yönelik nitel bir sürecin izlendiği araştırma olarak tanımlamaktadır. Nitel araştırma yöntemleri içinde yer alan durum çalışmasında ise amaç belirli bir duruma ilişkin sonuçlar ortaya koymaktır. Bir duruma ilişkin ortam, kişiler, olaylar, süreçler gibi etkenler bütüncül bir yaklaşımla araştırılır ve ilgili durumu nasıl etkiledikleri ve ilgili durumdan nasıl etkilendikleri üzerine odaklanılır. Bununla birlikte bir durumda meydana gelen değişimleri ve süreçleri anlamak için de durum çalışmasından yararlanılabilir (Yıldırım ve Şimşek, 2016, s. 73).

\section{2. Çalışma Grubu}

Bu araştırmanın çalışma grubunu Sinop İli şehir merkezinde yer alan üç devlet anaokulunda görev yapmakta olan okul öncesi öğretmenleri oluşturmaktadır. Araştırmaya dâhil edilen öğretmenler amaçlı örnekleme yöntemlerinden biri olan tipik durum örneklemesi yoluyla belirlenmiştir. Patton'a (1987) göre amaçlı örnekleme yönteminin bir türü olarak tipik durum örneklemesi ile amaç, tipik durum/kişilerle çalışma yoluyla belirli bir alan, durum hakkında fikir sahibi olmak veya bu alan, duruma yönelik yeterli bilgi sahibi olmayanları bilgilendirmektir (aktaran Yıldırım ve Şimşek, 2016, s. 120-121). Araştırma kapsamında buna yönelik olarak 2019 y1lında, Sinop şehir merkezindeki üç devlet anaokulunda görev yapan okul öncesi öğretmenlerine ulaşılmıştır. Bu okullar, sahip olduğu fiziksel imkânlar, öğretmen ve öğrenci sayıları bakımından benzer özellikler göstermektedir. Öncelikle İl Milli Eğitim Müdürlüğü ve okulların idarecileri aracılığı ile bu okullardaki öğretmenlerin tamamına duyuru yapılmış ve araştırma yazılı olarak tanıtılmıştır. Desteklemek amacıyla araştırmacı tarafından öğretmenlere tekrar ulaşılmış ve araştırmanın ayrıntılarına yönelik bilgi verilmiştir. Bu süreçler sonucunda derslerinde Orff Yaklaşımı’na yönelik uygulamalara yer verdiğini ifade eden ve araştırmaya katılmaya gönüllü olan 14 okul öncesi öğretmeni, araştırmanın çalışma grubunu oluşturmuştur.

\subsection{Verilerin Toplanması}

Araştırma kapsamında veri toplamaya yönelik olarak okul öncesi öğretmenleri ile görüşme yapılmıștır. Görüşme; sözlü iletişim yoluyla veri toplama tekniği olarak açıklanabilir (Karasar, 2005, s. 165). Araştırmada, Patton (1987) tarafindan sınıflandırılmış üç tür (sohbet tarzı görüşme, görüşme formu yaklaşımı, standartlaştırılmış açık uçlu görüşme) görüşme yaklaşımından biri olan görüşme formu yaklaşımından yararlanılmıştır. Patton'a göre (1987) 
görüşme formu yöntemi benzer konulara yönelmek yoluyla değişik insanlardan aynı tür bilgilerin alınması amacıyla hazırlanır (aktaran Yıldırım ve Şimşek, 2016, s. 131-132). Bu görüşme yaklaşımı görüşme sırasında irdelenecek bir sorular ve konular listesini kapsar. Görüşmeci önceden hazırladığı konu veya alanlara sadık kalarak hem önceden hazırlanmış soruları sorma hem de bu sorular konusunda daha ayrıntılı bilgi alma amacıyla ek sorular sorma özgürlügüne sahiptir. Görüşmeci görüşme sırasında soruların cümle yapısını ve sırasını değiştirebilir, bazı konuların ayrıntısına girebilir veya daha çok sohbet tarzı bir yöntem benimseyebilir (Yıldırım ve Şimşek, 2016, s. 132). $\mathrm{Bu}$ niteliklerinden ötürü görüşmeler süresince yapılandırılmış görüşme formundan yararlanılmıştır. Araştırmacı tarafından hazırlanan görüşme formu, iki alan uzmanının görüşlerinin de alınmasıyla -önerilen düzenlemelerle- son halini almıştır. Bununla birlikte görüşme süreçleri, yazılı notlara ek olarak ses kayıt cihazı ile de kayıt altına alınmıştır.

\subsection{Verilerin Analizi}

Araştırmada elde edilen verilerin analizinde nitel veri analizi yaklaşımlarından biri olan içerik analizinden yararlanılmıştır. İçerik analizi yoluyla elde edilen veriler tanımlanmaya ve verilerin içinde saklı olabilecek gerçekler ortaya çıkarılmaya çalışılır. Bu amaçla birbirine benzeyen veriler belirli kavram ve temalar çerçevesinde bir araya getirilir. Ardından okuyucunun anlayabileceği şekilde düzenlenerek yorumlanır (Yıldırım ve Şimşek, 2016, s. 242).

Buna yönelik olarak okul öncesi öğretmenlerinin eğitim-öğretim etkinliklerinde Orff Yaklaşımını kullanma durum ve düzeylerini tespit etmek amacıyla, önceden belirlenmiş kavramsal çerçeve içinde [Ses uygulamaları "Konuşma ve Şarkı söyleme öğrenme alanları", enstrüman çalma öğrenme alanı, hareket ve dans öğrenme alanı (Frazee, 1987'den aktaran Yaprak Kotzian, 2018, s. 101), çeşitli malzemeler kullanarak enstrüman tasarlama ve kullanma (Salmon, 2005, s. 27) başlıkları ile] kodlamalar yapılmıștır. Strauss ve Corbin (1990) tarafından 'daha önceden belirlenmiş kavramlara göre yapılan kodlama' olarak isimlendirilen bu kodlama türü ile araştırmanın temelini oluşturan bir kavramsal çerçeve kapsamında veriler toplanmadan önce bir kod listesi çıkarılır ve bu kod listesi, temalar ve/veya temalar altında yer alabilecek kavramlar düzeyinde olabilir (aktaran Yıldırım ve Şimşek, 2016, s. 244-245).

\section{Bulgular}

Tablo 1

Katılımcılara İlişkin Betimleyici Bulgular

\begin{tabular}{|c|c|c|c|c|}
\hline Öğretmen & Öğrenim durumu & Meslek hizmet yılı & Çalışmış olduğu öğrenci yaş grupları & $\begin{array}{c}\text { Şu anda çalışmakta olduğu öğrenci } \\
\text { yaş grubu }\end{array}$ \\
\hline $\begin{array}{l}\text { Araştırmaya } \\
\text { dâhil olan } \\
\text { öğretmenler } \\
\quad(\mathrm{f}=14)\end{array}$ & $\begin{array}{l}\text { Lisans } \\
(\mathrm{f}=14)\end{array}$ & $\begin{array}{l}* 10 \text { yil }(\mathrm{f}=4) \\
* 13 \text { yil }(\mathrm{f}=3) \\
* 12 \text { y1l }(\mathrm{f}=2) \\
* 11 \text { y1l }(\mathrm{f}=1) \\
* 14 \text { yil }(\mathrm{f}=1) \\
* 15 \text { yil }(\mathrm{f}=1) \\
* 16 \text { yil }(\mathrm{f}=1) \\
* 29 \text { y1l }(\mathrm{f}=1)\end{array}$ & $\begin{array}{c}* 3,4,5,6 \text { yaş grupları }(\mathrm{f}=7) \\
* 4,5,6 \text { yaş grupları }(\mathrm{f}=4) \\
* 4,5 \text { yaş grupları }(\mathrm{f}=1) \\
* 5 \text { yaş grubu ve özel eğitim }(\mathrm{f}=1) \\
* 5,6 \text { yaş grupları }(\mathrm{f}=1)\end{array}$ & $\begin{array}{l}* 4 \text { yaş grubu }(\mathrm{f}=5) \\
* 5-6 \text { yaş grubu }(\mathrm{f}=4) \\
* 5 \text { yaş grubu }(\mathrm{f}=3) \\
* 3 \text { yaş grubu }(\mathrm{f}=1) \\
* 3-4 \text { yaş grubu }(\mathrm{f}=1)\end{array}$ \\
\hline \multicolumn{3}{|c|}{ Orff Yaklaşımı'na ilişkin eğitim durumu } & \multicolumn{2}{|c|}{ Dersliklerin dans uygulamalarına uygunluğu } \\
\hline \multicolumn{2}{|c|}{$\begin{array}{c}\text { *Evet başlangıç düzey }(\mathrm{f}=5) \\
\text { *Evet teorik }(\mathrm{f}=1) \\
\text { *Hayır }(\mathrm{f}=8)\end{array}$} & $\begin{array}{r}* \mathrm{R} \\
* \text { Orff ezg } \\
\text { olm } \\
* \text { Orff ezg } \\
\text { oll }\end{array}$ & $\begin{array}{l}\text { tim Çalgiları }(\mathrm{f}=14) \\
\text { çalgılarından profesyonel } \\
\text { yan metalofon }(\mathrm{f}=12) \\
\text { çalgılarından profesyonel } \\
\text { ayan ksilofon }(\mathrm{f}=2)\end{array}$ & $\begin{array}{c}\text { *Gruplara ayrılarak yapılıyor, ihtiyaç halinde } \\
\text { büyük salon kullanılıyor }(\mathrm{f}=5) \\
\text { *Derslikler uygun }(\mathrm{f}=9)\end{array}$ \\
\hline
\end{tabular}

Tablo 1'de görüldüğü üzere araştırmaya dahil olan 14 öğretmenin tamamı lisans mezunudur. Meslek hizmet y1lları $10(\mathrm{f}=4), 13(\mathrm{f}=3), 12(\mathrm{f}=2), 11(\mathrm{f}=1), 14(\mathrm{f}=1), 15(\mathrm{f}=1), 16(\mathrm{f}=1)$ ve $29(\mathrm{f}=1)$ yıldır. Bu süreler zarfinda 7 öğretmenin 3,4,5,6 yaş grupları ile; 4 öğretmenin 4,5,6 yaş grupları ile; 1 öğretmenin 4,5 yaş grupları ile; 1 öğretmenin 5 yaş grubu ve özel eğitim öğrencileri ile ve son olarak 1 öğretmenin de 5,6 yaş grupları ile çalışmış oldukları tespit edilmiştir. Şu anda çalışmakta oldukları yaş grupları 3 ile 6 yaş aralığında değişmektedir (4 yaş grubu ( $\mathrm{f}=5), 5-6$ yaş grubu $(\mathrm{f}=4), 5$ yaş grubu $(\mathrm{f}=3), 3$ yaş grubu $(\mathrm{f}=1), 3-4$ yaş grubu $(\mathrm{f}=1))$.

4 öğretmen Orff Yaklaşımına yönelik kısa süreli uygulamalı eğitim programına dâhil olmuş, 1 öğretmen üniversite öğrenimi süresince müzik eğitimi dersleri kapsamında Orff Yaklaşımı uygulamalarına yönelik dersler almıştır. 1 öğretmen de Orff Yaklaşımı'nın tanıtımına yönelik teorik bilgilendirme toplantısına dâhil olmuş, kalan 8 öğretmen ise bu alanda herhangi bir eğitim programına dâhil olmamıştır.

Her öğretmenin ( $\mathrm{f}=14$ ) sınıfında müzik merkezi bulunmakta ve bu merkezde yoğunlukla ritim çalgıları yer almaktadır. Bununla birlikte profesyonel olmayan metalofonlar $(\mathrm{f}=12)$ ve profesyonel olmayan ksilofonlar da $(\mathrm{f}=2)$ ders vermekte oldukları sınıfların müzik merkezlerinde bulunan diğer çalgılardır. 
Dersliklerin bir kısmının ( $\mathrm{f}=5$ ) dans uygulamaları için öğrenci sayısının fazlalığı nedeniyle küçük kalabilmekte olduğu; bu problemin grup çalışmaları (iki ya da üç gruba ayrılıp) yapılarak çözüldüğü ve ihtiyaç halinde ortak büyük salonun kullanıldığı; bir kısmının da $(\mathrm{f}=9)$ hareket ve dans uygulamaları için öğrenci sayısına paralel olarak uygun olduğu tespit edilmiştir.

Tablo 2

Okul Öncesi Öğretmenlerinin Orff Yaklaşımı Temelli Ses Uygulamalarına İlişkin Tema ve Kodlar

\begin{tabular}{|c|c|}
\hline \multicolumn{2}{|c|}{ Ses uygulamaları } \\
\hline Konuşma öğrenme alanı & Şarkı söyleme öğrenme alanı \\
\hline $\begin{array}{c}\text { Artikülasyon ve konuşma egzersizleri }(\mathrm{f}=13) \\
\text { Ritmik egzersizler }(\mathrm{f}=10)\end{array}$ & $\begin{array}{c}\text { Şarkı repertuvarı }(\mathrm{f}=14) \\
\text { Hareket oyunları ve danslar }(\mathrm{f}=13) \\
\text { Nefes egzersizleri }(\mathrm{f}=8)\end{array}$ \\
\hline
\end{tabular}

Tablo 2'de okul öncesi öğretmenlerinin sınıf içi etkinliklerinde Orff Yaklaşımı temelli ses uygulamalarına (Konuşma öğrenme alanı ve şarkı söyleme öğrenme alanı) yer verme durumları görülmektedir. Okul öncesi öğretmenlerinden elde edilen veriler incelendiğinde konuşma öğrenme alanı içinde öğretmenlerin tamamına yakınının -farklı türde çalışma örnekleri ile- artikülasyon ve konuşma egzersizleri $(\mathrm{f}=13)$ ve ritmik egzersizlere ( $\mathrm{f}=10)$; şarkı söyleme öğrenme alanı içinde ise şarkı repertuvarı uygulamaları $(\mathrm{f}=14$ ) ile hareket oyunları ve dans çalışmalarına ( $\mathrm{f}=13$ ) yer verdiği, bununla birlikte öğretmenlerin yarısından fazlasının da nefes egzersizlerine yönelik uygulamalar $(\mathrm{f}=8)$ gerçekleştirdiği gözlenmektedir.

Tablo 3

Okul Öncesi Öğretmenlerinin Orff Yaklaşımı Temelli Sınıf Iç̧i Etkinliklerinde Hareket ve Dans Öğrenme Alanı Uygulamalarına İlişkin Tema ve Kodlar

\begin{tabular}{c}
\hline Hareket ve dans öğrenme alanı \\
\hline Dans/hareket doğaçlamaları $(\mathrm{f}=13)$ \\
Hareket repertuvarı $(\mathrm{f}=11)$ \\
Sabit dans formlarının uygulanması $(\mathrm{f}=8)$ \\
Bedensel farkındalık ve duyarlılaştırmaya yönelik çalışmalar $(\mathrm{f}=6)$ \\
Dans kompozisyonu $(\mathrm{f}=3)$ \\
Harekete eşlik etme $(\mathrm{f}=2)$ \\
\hline
\end{tabular}

Okul öncesi öğretmenlerinin sınıf içi etkinliklerinde Orff Yaklaşım'ını kullanma durumlarına ilişkin bir diğer tema hareket ve dans ögrenme alanına yöneliktir. Tablo 3'te görüldüğü üzere, bu tema kapsamında öğretmenlerin çoğunlukla -farklı türde çalışma örnekleri ile- dans/hareket doğaçlamaları (f=13) ve hareket repertuvarı uygulamalarına $(\mathrm{f}=11)$ yer verdiği, öğretmenlerin yarısına yakınının da sabit dans formlarına yönelik uygulamalara $(\mathrm{f}=8)$ ve bedensel farkındalık ve duyarlılaştırmaya yönelik çalışmalara ( $\mathrm{f}=6)$ yer verdiği gözlenmektedir. Az sayıda öğretmenin de dans kompozisyonu uygulamaları $(\mathrm{f}=3)$ ve harekete eşlik etme uygulamalarına $(\mathrm{f}=2)$ yer verdikleri gözlenmiştir.

Tablo 4

Okul Öncesi Öğretmenlerinin Orff Yaklaşımı Temelli Sınıf İçi Etkinliklerinde Enstrüman Çalma Alanı Uygulamalarina İlişkin Tema ve Kodlar

\begin{tabular}{c}
\hline Enstrüman çalma uygulamaları \\
\hline Ritmik egzersizler ve doğaçlama $(\mathrm{f}=13)$ \\
Topluluk müziği $(\mathrm{f}=10)$, \\
Tını kalitesi ve çalım teknikleri $(\mathrm{f}=4)$ \\
\hline
\end{tabular}

Okul öncesi öğretmenlerinin sınıf içi etkinliklerinde Orff Yaklaşımı'nı kullanma durumlarına yönelik olarak enstrüman çalma öğrenme alanı uygulamaları incelendiğinde (Tablo 4) öğretmenlerin tamamına yakınının ( $\mathrm{f}=13)$ ritmik egzersizler ve doğaçlama çalışmalarına, topluluk müziğine yönelik etkinliklere ( $\mathrm{f}=10$ ) yer verdikleri gözlenmektedir. Buna ek olarak az sayıda öğretmenin de $(\mathrm{f}=4)$ tını kalitesi-çalım tekniklerine yönelik uygulamalara yer verdiği tespit edilmiştir.

Tablo 5

Okul Öncesi Öğretmenlerinin Orff Yaklaşımı Temelli Sınıf Iç̧i Etkinliklerinde Enstrüman Tasarımı Uygulamaları ve Bu Enstrümanları Kullanma Durumlarına İlişkin Tema ve Kodlar

Okul öncesi öğretmenlerinin çeşitli malzemelerden faydalanarak enstrüman tasarlama ve kullanma durumlarına yönelik elde edilen veriler incelendiğinde öğretmenlerin tamamına yakınının ( $\mathrm{f}=13)$ çalgı tasarlama uygulamalarına yer verdikleri tespit edilmiştir. Öğretmenlerin tamamına yakını tasarladıkları çalgıların etkinlikler 
içinde kullanımını planlamakta; bu kapsamda çalgıların seslerini keşfetme, bireysel doğaçlamalar yapma, ses çalışmalarına eşlik etme uygulamalarına yer vermektedir.

\section{Sonuç}

Sınıf içi etkinliklerinde Orff Yaklaşımı temelli uygulamalara yer veren okul öncesi öğretmenlerinden elde edilen bulgular incelendiğinde, Orff Yaklaşımı'nda 'konuşma ve şarkı söyleme öğrenme alanlarına' yönelik olarak artikülasyon ve konuşma egzersizlerine, ritmik egzersizlere, şarkı repertuvarına yönelik çalışmalara, hareket oyunları ve dans uygulamaları ile nefes egzersizlerine yer verdikleri gözlenmektedir. Orff Yaklaşımı, dili, konuşmayı, ses oyunlarını ve şarkının kullanımını, hayal gücü ve yaratıcı ifadeyi geliştirmenin birincil araçları olarak görmektedir. $\mathrm{Bu}$ uygulamalar ile çocuklar, diğer kültürlerin dillerini deneyimleyebilir, topluluktaki birliktelik kavramını içselleştirebilirler, kendilerini ifade edebilme ve gerçekleştirebilme firsatı yakalayabilirler. Ayrıca bu uygulamalar, müzikal öğrenmenin bir aracı olarak da kullanılabilir (Colette Bischoff, 2009, s. 37). İçerdiği artikülasyon, ritmik, dinamik ve anlatım unsurları aracılığıyla temel bir sanatsal malzeme sunan konuşma, Orff Yaklaşımı'nın temel öğrenme alanlarından biridir. Konuşma, Orff Yaklaşımı’nda, insanın doğuştan getirdiği bir özellik olarak temel unsurları ile müzik eğitimine aktarılır (Frazee, 1987, Orff, 1978, Keller, 1973, Widmer, 1994' ten aktaran Yaprak Kotzian, 2018, s. 101-102). Konuşma alanı içerisindeki alıştırmalar Orff öğretisinin her aşamasında önemli rol oynar. Tekerlemeler, isimler, heceler, seslenmeler, sayışmacalar, atasözleri, özlü sözler, bilmeceler, hikayeler, şiirler; bir anlam ifade etmeyen-uydurmasyon ya da hayal ürünü kelimeler ve dörtlükler, Orff Yaklaşımı'nın çekirdeğini oluşturur (Öztürk, 2003, s. 141; Yaprak Kotzian, 2018, s. 103). Yaratıcı hareket, dil, basit şarkılar ve tını jestlerinin tümü süreç içinde başlangıç noktası olarak rol üstlenir. Böylece en doğal, temel ve kolay ulaşılabilir enstrüman olarak 'insan sesi' konuşma yoluyla temel bir ifade aracı olarak kullanılır (Colette Bischoff, 2009, s. 36).

Alan yazın, Orff Yaklaşımı içinde konuşma öğrenme alanının önemini ortaya koymaktadır. Araştırmaya dahil olan öğretmenlerin tamamına yakınının bu öğrenme alanı içinde 'artikülasyon ve konuşma egzersizleri ( $\mathrm{f}=13$ ) ile ritmik egzersizlere $(\mathrm{f}=10)$ yer veriyor olmasının, Orff Yaklaşımı'nın uygulama prensipleri bakımından önem taşıdığ düşünülmektedir.

Araştırma kapsamında okul öncesi öğretmenleri tarafından Orff Yaklaşımı temelli sınıf içi etkinliklerinde yer verildiği tespit edilen bir diğer öğrenme alanı ise şarkı söyleme öğrenme alanıdır. Müzik, ritim ve dil ayrılmaz bir bütündür. Okul öncesi eğitimde iyi hazırlanmış bir müzik eğitimi programı, çocuğun anadilinin gelişmesine büyük katkı sağlar. Çocuğu sıkmadan, zorlamadan, oyunlaştırarak söylenen tekerleme, sayışma ve şarkılar, çocuğun kelime dağarcığını zenginleştirirken dil çabukluğu kazanmasını sağlamakta, düzgün ve anlamlı cümleler kurmasına da yardımcı olmaktadır (Uçal, 2003, s. 14). Wuytack’a (1977) göre şarkı söylemek nefes akışını sese dönüştürmektir. Bu nedenle de en temel yaşam fonksiyonumuz olan 'solunumla' ilişkilidir. İnsan şarkı söylerken bedensel ve ruhsal olarak bir bütünleşme yaşar. Kişi sesini yükselttiğinde kendisinin de ötesine geçtiği aşkın bir durum yaşar (aktaran Colette Bischoff, 2009, s. 37). Yaprak Kotzian (2018) ise şarkı söyleme ve konuşma sesini, her insanın sahip olduğu ve doğallıkla kullanabildiği bir müzik enstrümanı olmanın yanında, insanın temel ifade araçlarından biri olarak tanımlar (s.104). Orff Yaklaşımı temel prensipleri ile örtüşen tüm bu niteliklerinden ötürü şarkı söylemek, eğitim süreçlerinde doğal bir ifade aracı olarak önemli bir yere sahip olur.

Orff Yaklaşımı, çocukların hayal gücünü, ilgisini ve yaratıcılığını harekete geçiren aktivite, oyun ve eğlenceli egzersizler aracılığı ile onların şarkı söyleme yeteneğinin gelişimi ve güçlenmesine katkı sağlamaya çalışır (Yaprak Kotzian, 2018, s. 104-105). Araştırmaya dahil olan öğretmenlerin tamamının ve tamamına yakınının şarkı söyleme öğrenme alanı içinde şarkı repertuvarı çalışmaları ( $\mathrm{f}=14$ ) ile hareket oyunları ve dans uygulamalarına $(\mathrm{f}=13)$ yer veriyor olmasının, Orff Yaklaşımı'nın uygulama prensipleri bakımından önem taşıdığ düşünülmektedir.

Bununla birlikte Orff Yaklaşımı'nda şarkı söyleme öğrenme alanına yönelik olarak üzerinde durulan uygulamalardan biri de nefes çalışmalarıdır. Nefes çalışmaları çoğunlukla; hayali cisimleri zihninde canlandırmak, doğa olaylarını tasavvur etmek, bir partner ile hareket etmek, küçük hikayeler aracılığı ile kişinin kendi bedenine bir yolculuğa çıkmasını sağlayan tanımlamalar yapmak vb. yaratıcı ve eğlenceli uygulamalarla gerçekleştirilir. Bu egzersizler ile nefes kapasitesi arttırılmaya ve güçlendirilmeye çalışılır. Nefes akışını ve sesi kontrol altına almak için diyafram aktive edilir (Wieblitz, 2011, Keetman, 1977 ve Orff, 1978'den aktaran Yaprak Kotzian, 2018, s. 104-105). Nefes çalışmaları, çocukların dil-konuşma ve şarkı söyleme becerilerini geliştirmeye yönelik uygulamalarda hazırlayıcı bir rol oynar. Bu nedenle araştırma kapsamında nefes çalışmalarının, öğretmenlerin yarısından fazlası $(\mathrm{f}=8)$ tarafından etkinliklerde uygulanıyor olması, Orff Yaklaşımı'nın uygulama prensipleri bakımından önemli bulunmuştur.

Araştırmaya dâhil olan okul öncesi öğretmenlerinin hareket ve dans öğrenme alanına yönelik olarak; dans/hareket doğaçlamalarına, hareket repertuvarı çalışmalarına, bedensel farkındalık ve duyarlılaştırmaya yönelik çalışmalara, sabit dans formları uygulamalarına, dans kompozisyonu ve harekete eşlik etme çalışmalarına yer verdikleri tespit edilmiştir. Orff Yaklaşımı’nda hareket ve dans alanındaki deneyimler, 'hareket oyunları, şarkılı oyunlar ve danslar, 
yaratıcı dans, halk dansları, hareket eşliği alıştırmaları, jimnastik egzersizleri, ritmik egzersizler vb.' kullanılarak kazandırılmaya çalışılır (Yaprak Kotzian 2018, s. 113). Bu uygulamalar kapsamında yaratıcı dans çalışmaları ile çocuklar koşma, sıçrama, zıplama, düşme, eğilme, dönme gibi hareketleri, zaman-mekân boyutları ve enerji gibi dans konseptleri ile bağlayabilir (Coogan, 2006, s. 20), sabit dans formlarını kullanarak farklı kültürlere ait dansları (ve böylelikle dansa eşlik eden müzikleri-şiirleri) tanıma ve deneyimleme imkânı yakalayabilir. Çeşitli enstrümanların seslerini harekete dönüştürebilir ya da hareketlerini çeşitli enstrümanlarla sese aktarabilir. Bu öğrenme alanına yönelik çalışmaların tamamı, okul öncesi dönem çocuklarının hareket alanında edineceği çok önemli devinişsel becerileri içinde barındırmaktadır.

Hareket çalışmaları, öğrencilere aktif olma, sosyal etkileşimlere girme ve bedeni bir ifade aracı olarak şekillendirme firsatı verir (Jorgenson, 2010, s. 31). Bedenin sağ ve sol taraflarının, alt ve üst kısımlarının eşzamanlı kullanımını, bedenin hareket yatkınlığının bütün olarak gelişmesini sağlar (Milli, 2016-2017, s. 21). Araştırma kapsamında öğretmenlerin tamamına yakınının dans/hareket doğaçlamaları uygulamaları (f=13) ile hareket repertuvarına yönelik uygulamalara $(\mathrm{f}=11)$ yer verdiği, yarısına yakınının da bedensel farkındalık ve duyarlılaştırmaya yönelik çalışmalar $(\mathrm{f}=6)$ ve sabit dans formlarına yönelik uygulamalara $(\mathrm{f}=8)$ yer verdiği tespit edilmiştir. Ancak Orff Yaklaşımı temelli hareket ve dans uygulamaları içinde dans kompozisyonu ( $\mathrm{f}=3$ ) ve harekete eşlik etme çalışmalarına ( $\mathrm{f}=2$ ) yer veren öğretmen sayısının düşük olduğu gözlenmiştir. Öğretmenlerin Orff Yaklaşımı'na yönelik eğitim-öğretim etkinliklerine katılabilme durumları göz önünde bulundurulduğunda (bkz. Tablo 1), bu durumun hareket ve dans alanına yönelik uygulama ve teorik bilgilerinin yetersizliğinden kaynaklandığı düşünülebilir. Benzer şekilde, Dalgın ve Acay Sözbir (2019, s. 55) 15 okul öncesi öğretmeni ile gerçekleştirdikleri araştırmada, öğretmenlerin müzik etkinliklerinde Orff Yaklaşımı'ndan yararlandığını, bununla birlikte en az yer verilen çalışmalardan birinin de 'yaratıcı hareket ve dans' uygulamaları olduğunu tespit etmişlerdir. Oysa hareket etmeye, oyun oynamaya çok yatkın olan çocukların buna yönelik duyacakları istek, müzik etkinliklerinde yapacakları danslarla, dramatizasyonlarla karşılanmalıdır. Çocuklar böylece kendi doğal hareketlerinden yola çıkar ve öğretmenin yönlendirmesiyle yapılandırılmış bir bütüne ulaşır. Kendi bulduğu hareketleri kullanıyor olmak da özgüvenlerinin artmasını sağlar. Çocuk böylece hayal gücünü kullanıp yaratıcılığını geliştirme firsatı yakalar (Özevin, 2003, s. 13).

Dans etmek, müziğin ritmine göre hareket etmek, bireyde 'amaca yönelik bilinçli hareketlerin devamlılığ1 ve ahenkli, uyumlu çalışması' olarak tanımlayabileceğimiz eş güdümün de göstergesidir. Bedenin olgunluğu arttıkça ve buna paralel olarak alıştırmalar çoğaldıkça eşgüdüm artar. Müziğin ve hareketin aynı anda derslerde kullanılmasının, beynin bazı odalarını doğrudan bazılarını dolaylı ve sonuç olarak her iki lobu ve odaları aynı anda çalıştırma gibi olağanüstü etkileri vardır (Tokatlı, 2014-2015, s. 13). Alan yazının ortaya koyduğu tüm bu nedenlerden ötürü Orff Yaklaşımı öğrenme alanlarından hareket ve dans alanı uygulamalarının bilinçli ve etkin şekilde eğitim-öğretim süreçlerine aktarılması büyük önem taşır. Bu durum, Orff Yaklaşımı uygulama prensipleri bakımından vazgeçilmezdir. Öğretmenlerin hareket ve dans öğrenme alanı uygulamalarına yönelik eğitim-öğretim süreçlerine dâhil olmalarının, sınıf içi etkinliklerindeki eksikliklerin giderilmesine katkı sağlayacağı düşünülmektedir.

Araştırmaya dâhil olan öğretmenlerin, Orff Yaklaşımı temelli sınıf içi etkinliklerinde yer verdiği bir diğer öğrenme alanı olan enstrüman çalma uygulamalarına yönelik verileri incelendiğinde; ritmik egzersizler ve doğaçlama çalışmaları, topluluk müziği, tını kalitesi ve çalım tekniklerine yönelik çalışmalar gerçekleştirdikleri tespit edilmiştir. Orff Yaklaşımı'nın enstrüman çalma uygulamalarında kullanılan Orff çalgıları, eğitim süreçlerinin önemli öğelerinden biridir. Farklı kültürlerden gelen bu çalgıların her biri kendine ait bir tınıya sahiptir. Melodik Orff çalgıları (ksilofonlar ve metalofonlar) ve birçok değişik sese sahip küçük vurmalı çalgılar, davullar, sahip oldukları kolay çalım teknikleri ile uygulamalar içinde herkes tarafindan rahatlıkla kullanılır (Erol, 2006, s. 18).

Enstrüman çalma uygulamalarında Orff çalgıları kullanılarak hem solo hem de grup çalışmaları içinde müzik yapılabilir. Kullanılan çalgılar, doğaçlamaya uygun yapıları ile ses fantezileri geliştirebilmeye de olanak sağlar (Schumacher, 2003, s. 6). Ayrıca bu çalgılar, hikâye anlatımında, değişik türlerde şarkı ve müziklere eşlik etmede kullanılabilirler. Orff Yaklaşımı'nın çocuklara ksilofon, davul vb. enstrümanları öğretmek gibi bir amacı yoktur. Aksine Orff Yaklaşımı'nda enstrümanlar, çocukların oyun, hareket, ritim, yaratıcılık ve birlikte çalışmanın birbiriyle iç içeliği hakkında bütüncül bir fikir edinmesi için kullanılır. Ayrıca bu çalgılar ile gerçekleştirilen çalma uygulamaları çocuklara, daha fazla yaratmaları, keşfetmeleri, duygularını ifade etmeleri ve doğaçlama yapabilmeleri için fırsatlar sunar (Jorgenson, 2010, s. 39-40). Araştırma kapsamında çalma alanına yönelik olarak öğretmenlerin büyük çoğunluğunun ritmik egzersizler ve doğaçlama $(f=13)$ ve topluluk müziği (f=10) uygulamalarına yer veriyor olduğu gözlenmiștir. Ancak öğretmenlerin bireysel ve topluluk müziğinde melodik egzersizler ve doğaçlamaya yeterince yer vermediği tespit edilmiştir. Öğretmenler bunun nedeninin 'müzik bilgi birikimlerinin ezgili çalgıları kullanmakta yetersiz olması ve bu çalgıların (profesyonel ezgili çalgılar) dersliklerinde bulunmaması' olduğunu ifade etmişlerdir (bkz. Tablo 1). Bununla birlikte Yaprak Kotzian (2018) Orff Yaklaşımı'nda enstrüman çalma öğrenme alanına ilişkin; Ritmik ve melodik egzersizler doğaçlama, topluluk müziği alıştırmalarına ek olarak tını kalitesi ve çalım tekniklerine yönelik çalışmalara da değinmektedir (s. 108- 
112). Ancak araştırmaya dahil olan az sayıda öğretmenin $(\mathrm{f}=4)$ tını kalitesi ve çalım teknikleri uygulamalarına yer verdiği gözlenmiştir.

Okul öncesi dönemde Orff çalgıları gibi çalınması kolay çalgıları çalmayı deneyen çocuklarda, tüm kaslar birbiriyle eşgüdüm içerisinde çalışmayı öğrenmektedir. Bunun yanında, çalgıdan ses çıkarmayı başarabildiğini gören çocuğun özgüveni sağlanmakta ya da artmaktadır (Uçal, 2003, s. 14). Bu nedenle okul öncesi dönem müzik etkinliklerinde bu çalgıların etkin şekilde kullanımı önem taşımaktadır. Orff çalgıları, Orff Yaklaşımı uygulamaları açısından da özel bir yere sahiptir. Araştırmaya dahil olan öğretmenlerin, enstrüman çalma öğrenme alanı uygulamalarını etkin bir şekilde gerçekleştirebilmeleri için, öğrenci sayısı ile uyumlu sayı ve çeşitlilikte (Orff Yaklaşımı'nda kullanılan) profesyonel çalgılara sahip olmaları gerekmektedir. Bununla birlikte müzik alan bilgilerinin de bu çalgıları çalmalarına ve toplu çalma etkinlikleri tasarlayabilmelerine imkân verecek düzeyde olması önem taşımaktadır. Kalyoncu (2008, s. 22) eğitimcilerin yaşamış oldukları bu problemlere değinmiş ve diğer müzik çalışmalarında olduğu gibi elementer müzik alıştırmalarında kullanılacak çalgıların ve kaynak kitapların maliyetlerinin oldukça yüksek olduğuna dikkat çekmiştir. Bununla birlikte öğreticilerin eğitimi ve gerekli malzemelerin temini için yasal düzenlemelerin yapılmamış olmasının, bu eğitim yaklaşımının kurumsallaşamamasına ve uygulamaların çoğunlukla kişisel girişimlerle sınırlı kalmasına neden olduğuna vurgu yapmıştır. Bu değerlendirmeler göz önünde bulundurulduğunda; araştırmaya dahil olan okul öncesi ögretmenlerine gerekli materyal ve eğitim desteğinin verilmesi ile sınıf içi etkinliklerinde enstrüman çalma öğrenme alanı uygulamalarına yönelik eksikliklerin giderilebileceği düşünülmektedir.

Orff Yaklaşımı uygulamaları içinde yer alan yaratıcı bir çalışma boyutu da çocukların çeşitli malzemeler kullanarak çalgılar tasarlaması ve bu çalgılarla müzikal deneyimler edinmeleridir. Çalg1 yapımı çeşitli materyallerin dokunarak tanınmasından, deneme yapmaya, kendi çalgısını üretmeye ve biçimlendirmeye uzanan bir yoldur (Salmon, 2005, s. 27). Her türlü materyal ve araç-gereç kullanılarak enstrüman tasarlamak hedeflenir (Erol, 2005, s. 42). Artık malzemelerin kullanımı, doğadan çeşitli taşlar, yapraklar vb. malzemelerle tasarlanan çalgılar örnek gösterilebilir. Sungurtekin (2001, s. 178) çalgı tasarlamada atık malzemelerin kullanımına 'farklı boyutlardaki boş pet şişelere taş, kum, pirinç, nohut, cam kırıkları vb. gibi malzemeler koyarak marakaslar hazırlama, konserve kutularından bongolar ve yoğurt kaplarından da küçük trampetler yapma' örneklerini vermiştir. Ayrıca Erol (2015) 'Kendin Yap Kendin Çal' isimli kitabında, Öztürk (2007) 'Nesneler ve Çalgılar' isimli kitabında müzik eğitim etkinliklerinde kullanılmak üzere benzer çalg1 yapım örneklerine yer vermiştir. Bu şekilde basit çalgılar yapmak çocukların tınıyı bilinçli olarak keşfetmesini desteklemektedir. Bu çalışmalar boyunca çocukların deneme, karşılaștırma, çalma/oynama, yaratıcı düşünme süreçleri teşvik edilir. Kendi çalgılarını tasarlıyor olmak çocuklar için ilgi çekici olduğundan müziğe ilgi duymalarını da sağlar (Salmon, 2005, s. 27).

Araştırmaya dâhil olan öğretmenlerin tamamına yakınının öğrencileri ile birlikte artık ve kolay erişilebilir malzemeler kullanarak çalgı tasarımı yaptıkları gözlenmiştir. Öğretmenler öncelikli olarak bu çalgılarla tını keşfine yönelik uygulamalar yaptıklarını, buna ek olarak zaman zaman etkinlikler içinde eşlik çalgısı olarak kullandıklarını ifade etmişlerdir. Orff Yaklaşımı uygulama prensipleri bakımından bu uygulamalara yer veriyor olmalarının önemli olduğu düşünülmektedir.

Sonuç olarak bu araştırmada araştırmaya dahil olan öğretmenlerin büyük bölümünün ses çalışmaları başlığı altında konuşma öğrenme alanında artikülasyon ve konuşma egzersizleri ve ritmik egzersizlere yer verdiklerini, şarkı söyleme öğrenme alanında ise şarkı repertuvarı, hareket oyunları ile danslara yönelik çalışmalar ve nefes egzersizi çalışmalarına yer verdiklerini ortaya koymuştur. Hareket ve dans öğrenme alanında ise çok sayıda öğretmenin dans/hareket doğaçlamalarına ve hareket repertuvarına yönelik çalışmalara yer verdiği ve öğretmenlerin yaklaşık yarısının bedensel farkındalık ve duyarlılaştırma ile sabit dans formlarının uygulanmasına yönelik çalışmalar gerçekleştirdiği tespit edilmiştir. Bununla birlikte az sayıda öğretmenin de dans kompozisyonu ve harekete eşlik etme çalışmalarına yer verdiği tespit edilmiştir. Enstrüman çalma öğrenme alanında da öğretmenlerin tamamına yakını ritmik egzersizler ve doğaçlama ve topluluk müziği çalışmalarına yer verirken, az sayıda öğretmenin çalgılara yönelik tını kalitesi ve çalım tekniklerine yönelik çalışmalara yer verdiği gözlenmiştir. Ayrıca ögretmenlerin tamamına yakınının farklı malzemeler kullanarak enstrüman tasarlama çalışmalarına yer verdiği tespit edilmiştir.

Orff Yaklaşımı, öğrenme alanlarının tamamının birbiriyle bağlantılı olarak kullanılmasını öngörür. Elbette bunun gerçekleşebilmesi için Orff Yaklaşımı'ndan yararlanan öğretmenin, önemle üzerinde durulan öğrenme alanlarına yönelik çalışmaların boyutlarına, içeriklerine, uygulama prensiplerine ve uygulama örneklerine yönelik bilgi ve deneyim sahibi olması beklenir. Böylelikle eğitmen, çocuklar için uzun süreli müzikal kazanımlara ulaşmada çok boyutlu, zengin bir öğrenme ortamı sağlayabilir. Araştırmaya katılan okul öncesi öğretmenlerinin, bu alana yönelik bilgi ve deneyimlerinin yetersiz olabilmesi ve bilgiye ulaşmakta zorlanabilmeleri, derslik koşullarının yetersizliği, dersliklerde bulunan enstrümanların nitelik ve/veya sayısal olarak yetersizliği gibi nedenlerden ötürü uygulamalarda bazı öğrenme alanlarına yeterince yer veremedikleri gözlenmiştir. 
$\mathrm{Bu}$ araştırma kapsamında yalnızca 'sınıf içi etkinliklerinde Orff Yaklaşımı temelli uygulamalara yer verdiklerini beyan eden okul öncesi öğretmenleri’ ile görüşme yapılmış ve veri toplanmıştır. Araştırmaya dâhil olan öğretmenler Orff Yaklaşımı eğitmenliğine yönelik uzun süreli ve aşamalandırılmış bir eğitim-öğretim programına dahil olmamıştır (bkz. Tablo 1). Araştırmada öğretmenlerin, Orff Yaklaşımı’nın kullanımına ilişkin yetkinliklerini; mesleki deneyimlerin diğer meslektaşlar ile paylaşımı ve profesyonel olmayan kaynaklar (vloglar, bloglar, internet siteleri, sosyal medya) aracılığı ile edindikleri tespit edilmiştir. Bu nedenle alana yönelik uzman rehberliğinde uygulamalı ve teorik içerikleri olan sistematik eğitim-öğretim süreçlerine ihtiyaç duydukları gözlenmiştir. Görüşmeler süresince araştırmaya dâhil olan öğretmenlerin tamamı da böyle bir desteğe ihtiyaç duyduklarını ifade etmişlerdir.

Orff Yaklaşımı uygulamalarında yer alan 'kulak eğitimi, müzik teorisi, elementer kompozisyon ve elementer müzik tiyatrosu gibi farklı öğrenme alanlarına (Frazee 1987'den aktaran Yaprak Kotzian, 2018, s. 101) yönelik durum incelemesi bu araştırmaya dâhil edilmemiş, araştırma; konuşma ve şark1 söyleme öğrenme alanları (araştırma kapsamında ses uygulamaları başlığı altında ele alınarak), hareket ve dans öğrenme alanı, enstrüman çalma öğrenme alanı (Frazee 1987'den aktaran Yaprak Kotzian, 2018, s. 101) ile sinırlı tutulmuştur. Ayrıca incelenen öğrenme alanlarına yönelik 'uygulamaların niteliği ve sıklığına' ilişkin gözlem ve inceleme de yapılmamıştır. Bu nedenle farklı araştırmalarla, Orff Yaklaşımı uygulamalarında önemle üzerinde durulan tüm ögrenme alanlarının erken müzik eğitiminde kullanılma durumu, daha kapsamlı ölçütler kullanılarak incelenebilir. Böylelikle uygulamalara yönelik eksikliklerin tespit edilerek giderilmesine katkı sağlanacağı düşünülmektedir. 


\section{Kaynakça}

Bilen, S., Özevin, B., \& Canakay, E. U. (2017). Orff destekli etkinliklerle müzik eğitimi. Müzik Eğitimi Yayınlar1.

Colette Bischoff, S. (2009). Music, growth, and wisdom: The educational thought of Carl Orff and Alfred North Whitehead [Yüksek lisans tezi, Saskatchewan Üniversitesi]. Saskatchewan Üniversite Kütüphanesi. https://harvest.usask.ca/handle/10388/etd-04092009-123506

Coogan, C. (2006, İlkbahar). Danstan söze yüksek uçuş. Orffinfo, 9, 20-24.

Çelebioğlu, Ö. (2017). Okul öncesi dönem müzik eğitiminde ortam düzenleme. İ. Artan (Ed.), Okul öncesi dönemde müzik eğitimi (s. 27-41) içinde. Hedef CS Basın Yayın.

Dalgın, M., \& Acay Sözbir, S. (2019). Okul öncesi dönem müzik etkinliklerinde uygulanan yöntem, teknik ve yaklaşımlar. Fine Arts, 14(1), 39-59. http://dx.doi.org/10.12739/NWSA.2019.14.1.D0225

Eren, B., Deniz, J., \& Düzkantar, A. (2013). Orff yaklaşımına göre hazırlanan müzik etkinlikleri içinde ipucunun giderek azaltılması yöntemi ile yapılan gömülü öğretimin otistik çocuklara kavram öğretmedeki etkililiği. Kuram ve Uygulamada Eğitim Bilimleri, 13(3), 1863-1887. https://doi.org/10.12738/estp.2013.3. 1499

Erol, O. (2005, Sonbahar). Orff enstitüsünde 1 yıl. Orffinfo, 8, 40-42.

Erol, O. (2015). Kendin yap kendin çal. Eğiten Kitap.

Frazee, J. (1987). Discovering Orff: A curriculum for music teachers. Schott.

Jorgenson, L. B. (2010). An analysis of the music education philosophy of Carl Orff [Yüksek lisans semineri, Wisconsin-La Crosse Üniversitesi].MINDS@UW. http://digital.library.wisc.edu/1793/49113

Kalyoncu, N. (2008, İlkbahar). Elementer müzik ve hareket eğitimi yaklaşımının Türkiye'de kabul sorunu üzerine. Orffinfo, 13, 20-23.

Karasar, N. (2005). Bilimsel araştırma yöntemi-kavramlar-ilkeler-teknikler. Nobel Yayın Dă̆ıtım.

Keetman, G. (1977). Elementaria: First acquaintance with Orff-Schulwerk. Schott. (Orijinal çalışma “Elementaria: Erster umgang mit dem Orff-Schulwerk" ismiyle 1970 y1lında yayınlandi).

Keller, W. (1973). Ludi musici, Sprachspiele. Fidula, Boppard am Rhein.

Koçak, K. O. (2013). Pedagojik profesyonellik ve Orff Schulwerk veya pusulayla yolunu bulmak. K. O. Koçak ve N. Laslo (Eds.), Türkiye'de Orff Schulwerk müzik, oyun ve dans üzerine makaleler (s. 7-13) içinde. Müzik Eğitimi Yayınları.

Milli Eğitim Bakanlığı. (2013). Okul öncesi eğitim programı. Milli Eğitim Bakanlığı Temel Eğitim Genel Müdürlüğü. http://tegm.meb.gov.tr/dosya/okuloncesi/ooproram.pdf

Milli, Z. M. (2016-2017, Sonbahar-Kış-İlkbahar). Orff Schulwerk’te beden üzerine/üzerinde oyunlar. Orffinfo, 24, 20-21.

Orff, C. (1978). The Schulwerk: Carl Orff-His life and works, documentation, C. 3. Hans Schneider.

Özevin, B. (2003, Eylül). Dokuz Eylül Üniversitesi Buca Eğitim Fakültesi Müzik Öğretmenliği Anabilim Dalı’nda Orff öğretisi. Orffinfo, 4, 12-13.

Öztürk, A. (2003). Yaratıcı drama ve Orff ögretisi arasındaki ilişki [Sempozyum sunumu]. Orff-Schulwerk müzik ve dans pedagojisi uluslararası sempozyum kitabı (s. 136-143) içinde. Orff-Schulwerk Eğitim ve Danışmanlık Merkezi.

Öztürk, A. (2007). Nesneler ve çalgılar (Artık araç gereçlerden çalgı yapımı). Kök Yayıncılık.

Patton, M. Q. (1987). How to use qualitative methods in evaluation. Sage Publications.

Salmon, S. (2005, Sonbahar). Herkes için müzik. Orffinfo, 8, 26-28.

Schumacher, K. (2003, Eylül). Müziği araç olarak kullanan sosyal pedagoji ve entegrasyon pedagojisi ile müzik terapisi açısından Orff-Schulwerk'in anlamı. Orffinfo, 4, 4-7.

Strauss, A. L., \& Corbin, J. (1990). Basics of qualitative research: Grounded theory procedures and techniques. Sage Publications.

Sungurtekin, Ş. (2001). Uygulamalı çevre eğitimi projesi kapsamında ana ve ilköğretim okullarında müzik yoluyla çevre eğitimi. Uludă̆ Üniversitesi Ĕgitim Fakültesi Dergisi, 14(1), 167-178. https://acikerisim.uludag.edu.tr/ bitstream/11452/10499/1/14 1 16.pdf 
Tokatlı, A. (2014-2015, Sonbahar-Kış-İlkbahar). Orff-Schulwerk: Çocuklarda hareket gelişimi ve eğitimi. Orffinfo, 23, 13-15.

Toksoy, A. C., \& Beşiroğlu, Ş. (2006). Orff Yaklaşımı çerçevesinde ilköğretim I. kademesinde müzik ve hareket eğitimine başlangıç için bir model önerisi. Itüdergisi/b Sosyal Bilimler, 3(2), 23-34. http://itudergi.itu.edu.tr/ index.php/itudergisi_b/article/viewFile/489/411

Türkmen, E. F. (2017). Müzik ĕgitiminde öğretim yöntemleri. Pegem Akademi.

Uçal, E. (2003, Eylül). Dokuz Eylül Üniversitesi Buca Eğitim Fakültesi Okul Öncesi Eğitimi Anabilim Dalı'ndaki Orff Öğretisi uygulamaları. Orffinfo, 4, 14-15.

Widmer, M. (1994). Sprache spielen: Vom kinderreim zur spielszene. Modelle zum spielerischen gestalten mit musik und tanz in kindergarten und elternhaus angeregt durch verschiedene sprachformen. Auer Verlag.

Wieblitz, C. (2011). Lively children's choir: Joyful, playful, dancing, incentives and examples. Reichert Verlag.

Wuytack, J. (1977). Apologia for Orff-Schulwerk. I. Carley (Ed.), Orff Re-Echoes book I: Selections from the Orff echo and the supplements (s. 3-9) içinde. AOSA.

Yaprak Kotzian, E. (2018). Orff-Schulwerk elementer müzik ve hareket pedagojisinin temelleri. Pan Yayınc1lık.

Yıldırım, A. (1999). Nitel araştırma yöntemlerinin temel özellikleri ve eğitim araştırmalarındaki yeri ve önemi. Eğitim ve Bilim, 23(112), 7-17. http://egitimvebilim.ted.org.tr/index.php/EB/article/view/5326/1485

Yıldırım, A., \& Şimşek, H. (2016). Sosyal bilimlerde nitel araştırma yöntemleri. Seçkin Yayıncılık. 